\title{
IMPROVING STUDENTS' HIGHER ORDER THINKING SKILL WITH STEM-ORIENTED E-MODULE
}

\author{
Nurul Chidayati $^{1 *}$, I Wayan Distrik ${ }^{2}$, Abdurrahman ${ }^{3}$ \\ ${ }^{1,2,3}$ Department of Physics Education, Postgraduate Program, Universitas Lampung, Indonesia
}

*Corresponding author: nurulchidayati@gmail.com

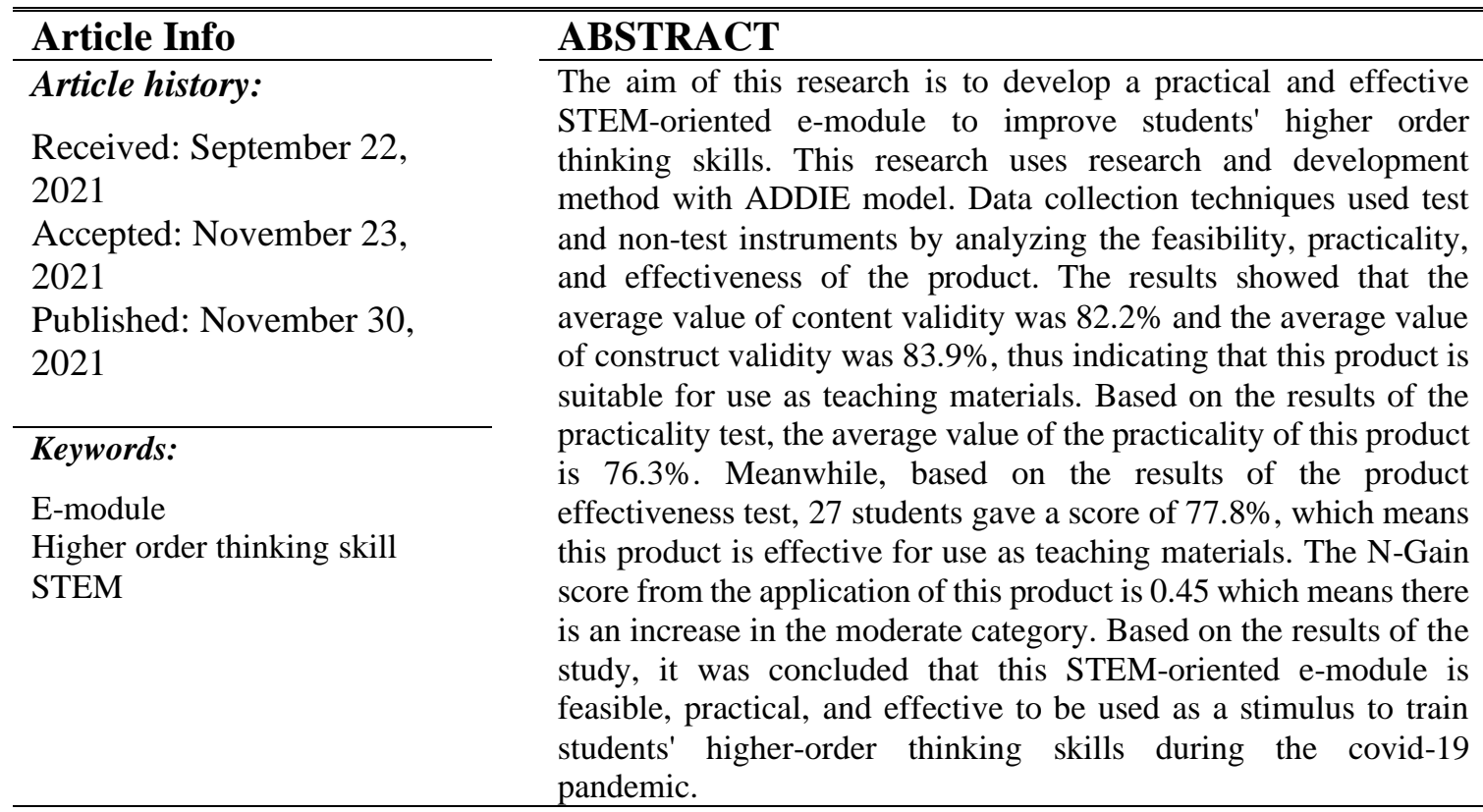

\section{MENINGKATKAN KETERAMPILAN BERPIKIR TINGKAT TINGGI SISWA DENGAN E-MODUL BERORIENTASI STEM}

\author{
Kata Kunci: \\ E-Modul \\ Keterampilan berpikir tingkat \\ tinggi \\ STEM
}

\section{ABSTRAK}

\begin{abstract}
Tujuan penelitian ini adalah untuk mengembangkan e-modul berorientasi STEM yang praktis dan efektif untuk meningkatkan keterampilan berpikir tingkat tinggi siswa. Penelitian ini menggunakan metode research and development dengan model ADDIE. Teknik pengumpulan data menggunakan instrumen tes dan non tes dengan mengannalisis kelayakan, kepraktisan, dan keefektifan produk. Hasil penelitian menunjukkan nilai rata-rata validitas isi sebesar $82,2 \%$ dan nilai rata-rata validitas konstruk sebesar $83,9 \%$, sehingga menunjukkan bahwa produk ini layak digunakan sebagai bahan ajar. Berdasarkan hasil uji kepraktisan, nilai rata-rata kepraktisan produk ini adalah $76,3 \%$. Sementara berdasarkan hasil uji keefektifan produk, 27 siswa memberikan nilai 77,8\% yang artinya produk ini efektif untuk digunakan sebagai bahan ajar. Skor N-Gain dari pengaplikasian produk ini adalah 0,45 berarti terdapat peningkatan dalam kategori sedang. Berdasarkan hasil penelitian, disimpulkan bahwa e-modul berorientasi STEM ini layak, praktis, dan efektif untuk digunakan sebagai stimulus untuk melatih keterampilan berpikir tingkat tinggi siswa di masa pandemi covid-19.
\end{abstract}




\section{INTRODUCTION}

Changes in the pattern of people's lives have entered the era of society 5.0 where all technology is part of humans [1][2]. This 5.0 industrial revolution emphasizes the readiness of the community to think more critically and develop creativity. Therefore, teachers as education drivers must be able to prepare qualified graduates, be able to compete globally, master technological developments, and be able to solve problems critically and creatively. But in reality in the field, the learning process that is carried out still often uses conventional learning models, namely in the form of using printed books from schools and only $36.1 \%$ use additional references for learning and only a small part uses technology-based learning to teach critical thinking.

According to Alimuddin, Director of Hafecs (Highly Functioning Education Consulting Services), in this era of industrial revolution 5.0 (society 5.0) teachers are required to provide more innovative and dynamic learning in the classroom teaching [3]. An example of an innovative technology-based learning product to address student needs is the e-learning module. E-Module is a form of teaching material that is used to help teachers and students in the learning process that is packaged in electronic form. EModules are made so that students can learn independently without guidance from a teacher [4][5]. By implementing e-modules, teachers do not need to directly teach students face-to-face, because e-modules contain lessons, methods, limitations, and evaluations that are designed systematically and attractively to achieve the expected competencies [6]. If the concept is abstract (like most concepts in physics), then the module is able to help students describe something abstract by using pictures, photos, charts, schematics, simulations, etc.

For teachers, the management of student abilities must really be considered, because education in the 21 st century needs to integrate knowledge, skills, attitudes, and mastery of technology [7][8]. Higher Order Thinking Skill (HOTS) is one of the most needed skills in the 21 st century in preparing students to face global challenges. Learning in the 21 st century requires four things that must be possessed, namely critical thinking skills, creativity, communication, and collaboration [9][10]. In addition to these four skills, an important thing that must be mastered in the 21 st century is technology, information, and communication literacy [11].

One of the lessons that teachers can do to improve students' higher order thinking skill is by applying STEM-based learning (Science, Technology, Engineering and Mathematics). STEM is a learning approach that involves the application of science, technology, engineering and mathematics to solve problems [12]. This is in line with the purpose of implementing the 2013 curriculum, which is to create students who have character and good character both to the Creator and to fellow human beings [13]. The 2013 curriculum focuses on a scientific education approach, which is an approach that emphasizes five steps in acquiring knowledge (observing, asking, reasoning, practicing, and managing) [14]. If students find a problem, they will be able to analyze, reflect, compose, create, give arguments (reasons), and apply concepts to different situations [15]. This ability is called higher order thinking ability. Higher order thinking skills include the ability to solve problems (problem solving), critical thinking skills, creative thinking, reasoning, and decision making [16][17]. The linkage of the STEM approach provides opportunities for students to improve higher order thinking skills in accordance with the demands of 21 st century learning.

Based on a preliminary study on students at SMK Karya Wiyata Punggur, it turned out that only $36.1 \%$ of students stated that they used references other than handbooks as additional sources of learning. Besides, during the Covid-19 pandemic, students study 
from home [18]. This certainly makes students experience a lack of understanding of physics concepts so that it provides a great opportunity for misconceptions. Therefore, the researcher developed a STEM-oriented e-module on the topic of mechanics and its application, to improve students' higher order thinking skills.

This E-Module will provide the learning that students need that can be used anywhere and anytime. In addition, e-modules provide assistance in understanding concepts through videos, pictures, and virtual lab practicum activities. This is in line with the results of the analysis of student needs where they need e-modules for independent study. The e-modules they need must contain explanations of concepts, videos, pictures, virtual labs and provide ways to solve problems in questions.

In line with preliminary research that has been carried out at vocational high schools majoring in automotive engineering and network communication engineering, that $92.6 \%$ of students stated that schools had not utilized technology optimally in the physics learning process. Physics is a difficult subject to understand, so that technology should be able to help students understand the process of learning physics [19]. Physics is needed by students as a basis for understanding scientific attitudes and making it easier for them to learn other subjects [20]. One of the scientific attitudes that must be developed by students is to always think further and be critical in concluding [21]. The thinking skills needed at the high school and college level are Higher Order Thinking Skills (HOTS) [22]. Higher Order Thinking Skills (HOTS) is the ability to solve problems by examining a problem and applying its knowledge to new situations [23][24]. In physics, symbols have a very important role to build knowledge, because some symbols in physics have the same shape but different meanings. In addition, an understanding of mathematics is also an important foundation for studying physics, especially for the topic of mechanics [25].

Mechanics is divided into subsections of Kinematics and motion dynamics, which are a part of physics that studies motion and force, and studies what causes motion. Newton's laws are the basic material for studying mechanics [26][27]. In addition, students must understand the concept of Newton's Law well and eliminate the tendency to memorize practical formulas in solving a problem.

Therefore, the researcher developed a practical and effective STEM-oriented emodule to improve vocational students' higher order thinking skills. The presence of videos, images, and virtual labs provides structural assistance in understanding this STEMoriented e-module. This is because the provision of videos, pictures, and practicum activities are arranged in stages according to sub-chapters to make it easier for students to study independently and allow them to understand concepts more easily in learning during the Covid-19 pandemic era.

\section{METHOD}

The aim of this research is to develop a practical and effective STEM-oriented emodule to improve students' higher order thinking skills. The method used is research and development with Dick \& Carrey's Analysis-Design-Development-ImplementationEvaluation (ADDIE) model modified by Branch [28]. The selection of the model is based on the consideration that this model pays attention to the basic stages of product development design that are simple and easy to understand. The ADDIE model uses 5 stages of development: (1) Analysis, (2) Design, (3) Development, (4) Implementation, and (5) Evaluation. A diagram of the concept of the ADDIE development model can be seen in Figure 1. 


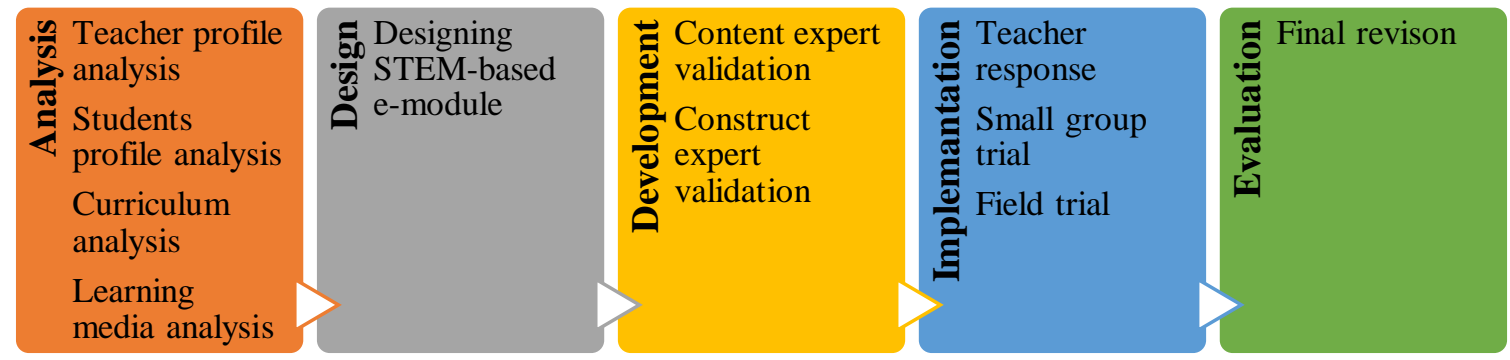

Figure 1. STEM-based E-Module Development Stages

Table 1. STEM-based E-Module Development Procedure

\begin{tabular}{|c|c|}
\hline ADDIE Model Stages & Developmment Stages \\
\hline \multicolumn{2}{|r|}{ Analyze } \\
\hline Teacher profile analysis & $\begin{array}{l}\text { Analyzing the results of the teacher needs analysis questionnaire related } \\
\text { to the models, methods, and media used during learning }\end{array}$ \\
\hline Students profile analysis & $\begin{array}{l}\text { Analyzing the results of the student needs analysis questionnaire related } \\
\text { to the implementation of learning so far }\end{array}$ \\
\hline Curriculum analysis & $\begin{array}{l}\text { Curriculum analysis is carried out to find out what curriculum is applied } \\
\text { in schools, as well as to analyze the syllabus to see the appropriate topics } \\
\text { for e-module }\end{array}$ \\
\hline Learning media analysis & $\begin{array}{l}\text { Learning media analysis aims to determine the media used by teachers } \\
\text { in the physics learning }\end{array}$ \\
\hline \multicolumn{2}{|r|}{ Design } \\
\hline Designing e-module & Creating initial designs for STEM-based e-modules \\
\hline \multicolumn{2}{|r|}{ Development } \\
\hline Constuct expert validation & $\begin{array}{l}\text { The construct expert validator analyzes and examines the instruments } \\
\text { used in the development of STEM-based e-module }\end{array}$ \\
\hline Content expert validation & $\begin{array}{l}\text { Content experts analyze the suitability of the material prepared with core } \\
\text { competencies and learning objectives. }\end{array}$ \\
\hline Media expert validation & $\begin{array}{l}\text { Media experts analyze and examine the feasibility of media, from word } \\
\text { choice, attractiveness of e-module presentation, language, text } \\
\text { presentation, and images as a whole. }\end{array}$ \\
\hline \multicolumn{2}{|r|}{ Implementation } \\
\hline Teacher response & The teacher gives constructive suggestions for the product \\
\hline Small group trial & Students provide comments/responses about this e-module \\
\hline Field trial & $\begin{array}{l}\text { The product was tested on a larger number of respondents with more } \\
\text { heterogeneous subjects }\end{array}$ \\
\hline \multicolumn{2}{|r|}{ Evaluation } \\
\hline Final revision & $\begin{array}{l}\text { Final revision. The result of this revision is the final product that is ready } \\
\text { to be used in schools }\end{array}$ \\
\hline
\end{tabular}

Data collection used non-test instruments in the form of construct expert validation sheets, content expert validation sheets, media expert validation sheets, $10^{\text {th }}$-grade physics teacher response questionnaire sheets, and $10^{\text {th }}$-grade student response questionnaire sheets. Data analysis was carried out to obtain the feasibility of STEM-based e-modules. which has been revised. The results obtained are used as consideration in improving the learning media. The non-test instrument was in the form of a questionnaire using a Likert scale. The Likert scale is used to measure attitudes, opinions, perceptions of a person or group about social events or phenomena [29]. While the test instrument used is a post-test of higher-order thinking skills. Data analysis techniques are in the form of product feasibility data analysis, product practicality, and product effectiveness. 


\section{RESULTS AND DISCUSSION}

The main result of this development research is a STEM-based e-module on Mechanics material to improve higher-order thinking skills. The stages of development are described in detail in the following points.

\subsection{Analyze}

The analysis is carried out in two stages, namely needs analysis and product analysis. Needs analysis is an activity to collect information about student learning needs. Based on the results of the questionnaire analysis of student needs filled out by all 108 students of grade 10 , it showed that $82.4 \%$ of students felt happy learning physics, but $92.6 \%$ of them had difficulties in learning physics. This is because $63.9 \%$ of students do not have additional textbooks or other learning resources. Another problem is learning that is done online. Online learning that has to be done at home creates displeasure, this is recognized by $64.8 \%$ of students. This is because $90.7 \%$ of students have difficulty understanding the concept of physics by themselves (because online learning provides limited interaction with the teacher) and $75 \%$ of students feel that there are too many assignments given by the teacher. In fact, $88 \%$ of students admitted that they only received physics lessons from teachers. This is in line with the expression of physics teachers who responded that they provided material through the summaries they prepared.

The next stage is to identify the e-module product by adjusting the objectives, learning objectives, learning content/materials, learning environment, and delivery strategies in learning. The identification results show that the concepts of force and motion studied in Newton's Laws are very important. This is because Newton's Laws are the basic concepts of subsequent materials such as work and energy, impulse and momentum, and much more. If you can't understand Newton's Law material, then students will have difficulty in learning the next material. Not only that, Newton's Law was chosen because it contains trigonometric concepts that students must understand. Therefore, the researcher chose to use Newton's Law material in the e-module as a product object to provide fun and easy-to-understand learning so that it can be used independently.

In addition, the stage of identifying the learning environment is also important in product identification because it serves to adjust the research objectives. This is based on the fact that learning at school is replaced by distance learning which is done at home. $91.7 \%$ of students own personal facilities such as laptops/computers, smartphones with internet connections. Therefore, the researcher uses WhatsApp which is used as a virtual class group. This is supported by the research of Pratama \& Yusro P which explains that WhatsApp integrated learning provides benefits to students including: (1) information and knowledge is quickly transferred easily, (2) the ease of creating discussion forums so that social media becomes a positive means for learning, (3) facilitating seamless collaboration between educators and students, (4) free and easy-to-use apps [30].

\subsection{Design}

The platform used to apply the STEM module as e-learning is the WhatsApp application. The first step in the initial product design is to design an attractive cover using Corel Draw, develop the components in the e-module such as material adapted to the STEM approach, images, sample questions, animations, audio, video, glossary, and evaluation tests. Furthermore, designing product concepts on paper, such as material presentation, providing videos and picture illustrations, examples of application in everyday life, sample questions, practice questions and tests of students' higher-order thinking skills, and designing product concept content. After finishing planning the 
contents of the product concept, the product in the form of an e-module is converted to pdf form. Furthermore, designing learning tools that are adapted to the curriculum used in schools, namely the 2013 curriculum.

Table 2. STEM Based E-Module Storyboard

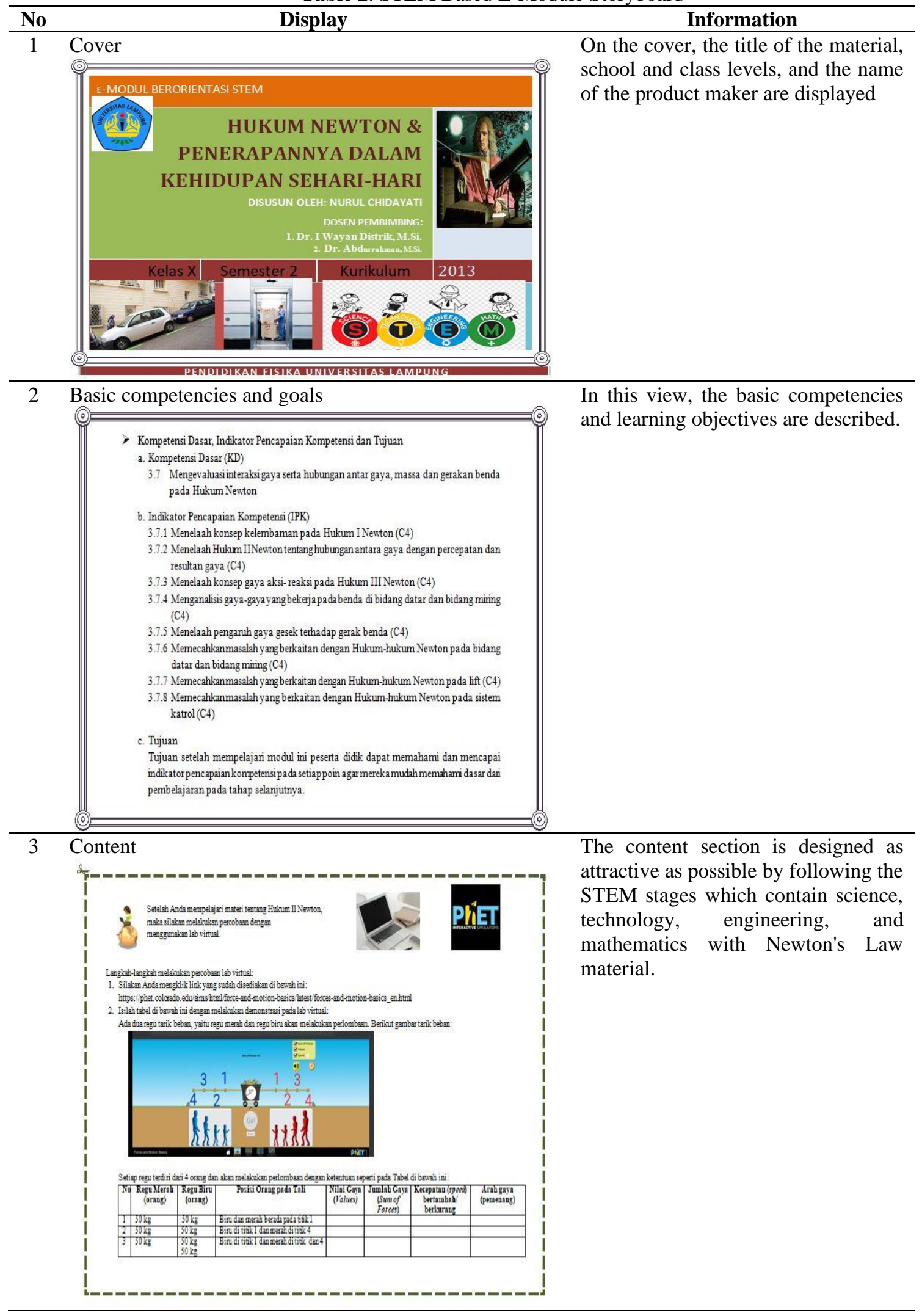




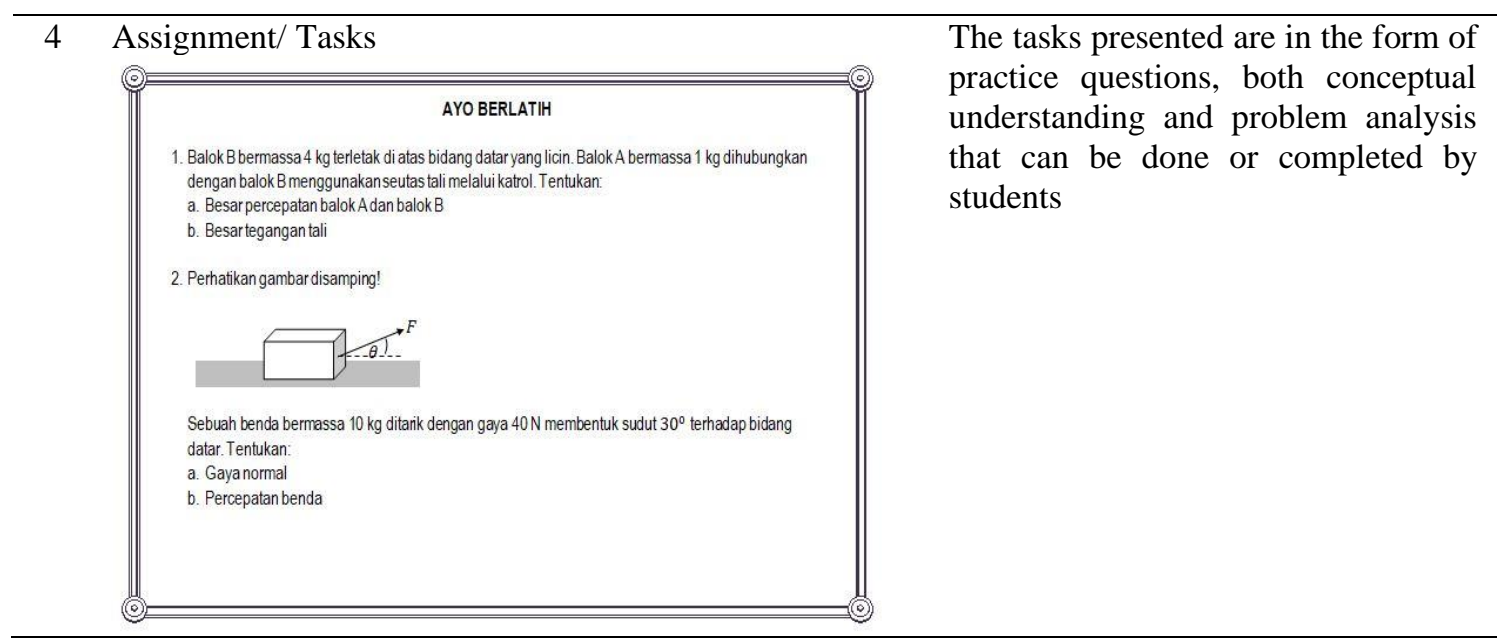

After the e-module is designed, the next step is the development stage. At the development stage, the researchers conducted a media feasibility test. Product validation is carried out after the initial product manufacture. Validation was carried out by experts, consisting of construct expert and content expert.

\subsection{Development}

At the development stage, researchers have produced products in the form of STEMbased e-modules on Newton's Law material to improve higher-order thinking skills. Furthermore, the researchers tested the feasibility of the product with a construct test and a content test.

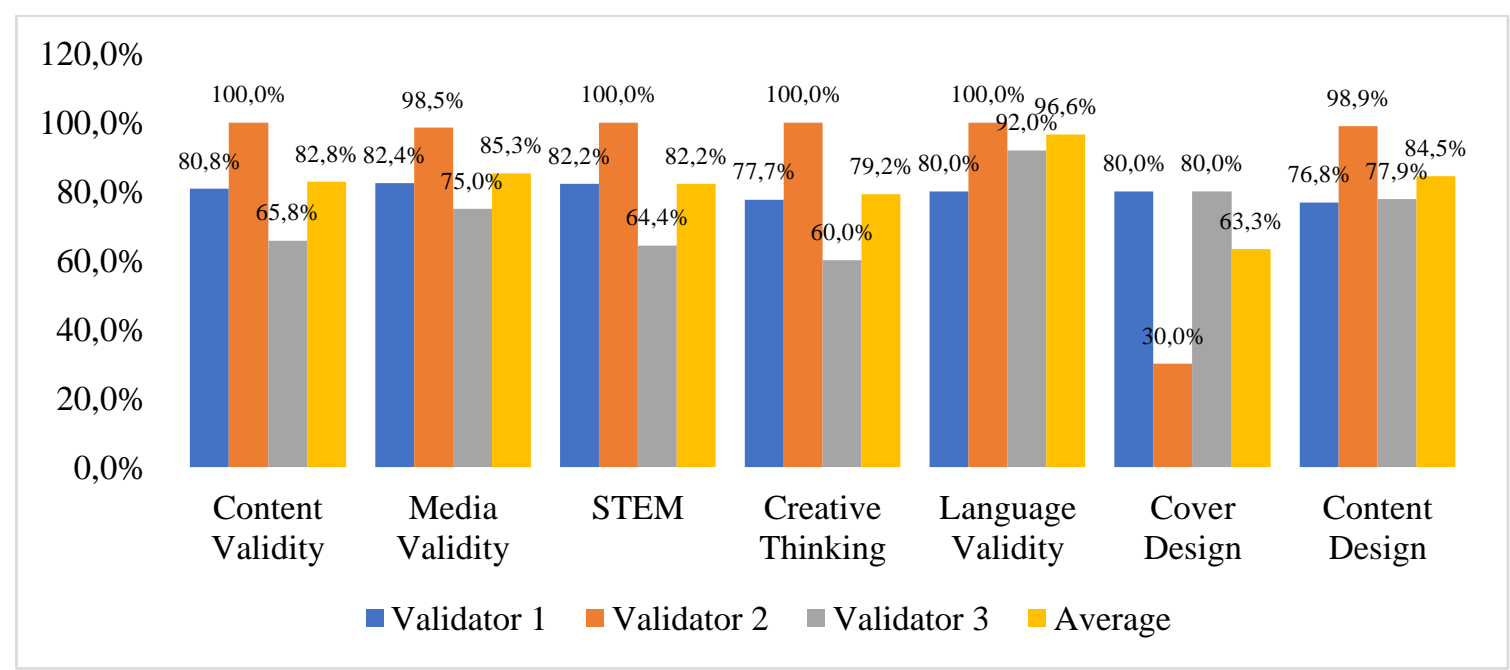

Figure 2. Product Validity Results

Based on the results of the product validity test as shown in Figure 2, it can be seen that the construct test consists of a content validity test, a STEM validity test, a critical thinking validity test, a language validity test, a cover test, and a content design test. Based on the results of the overall construct validity test, an average percentage of $82.02 \%$ was obtained with a very valid category and STEM-oriented e-modules were feasible to use with minor revisions.

After being validated by the validator, the e-module product was then tested on five students who were randomly selected for a one-on-one test (smal group trial). At this stage, five 10th graders were randomly selected. The test is carried out by giving e-module 
products to students to be used as independent learning media, then students are asked to fill out a questionnaire to assess criteria such as product attractiveness, ease of use, and can help students in learning. The questionnaire was presented with five answer choices "very appropriate", "appropriate", "fairly appropriate", "less appropriate", and "not appropriate". One-on-one test questionnaires are presented in a google form.

Based on the results of the one-on-one test assessment on the e-module attractiveness questionnaire, data obtained that $75 \%$ of students stated that the variations in the use of letters, illustrations in vector analysis, and the use of images were appropriate and interesting. And $100 \%$ of students stated that the content design was in accordance with the layout design of the e-module. The flow of content presentation is also very interesting and flowing, $75 \%$ of students stated that they easily understand the content of the e-module. All students also agree that the language used can be understood clearly so that it is easier for students to use the e-module. The results of the questionnaire on the usefulness of the e-module in the one-on-one test showed that $70 \%$ of students agreed that this e-module helped increase interest in learning, was enthusiastic about learning, and provided convenience in learning Newton's Laws. Not only that, but $75 \%$ of students also stated that this e-module is suitable for increasing curiosity, completing initial knowledge, and practicing questions, providing assistance to measure concept understanding and providing increased skills using physics learning media.

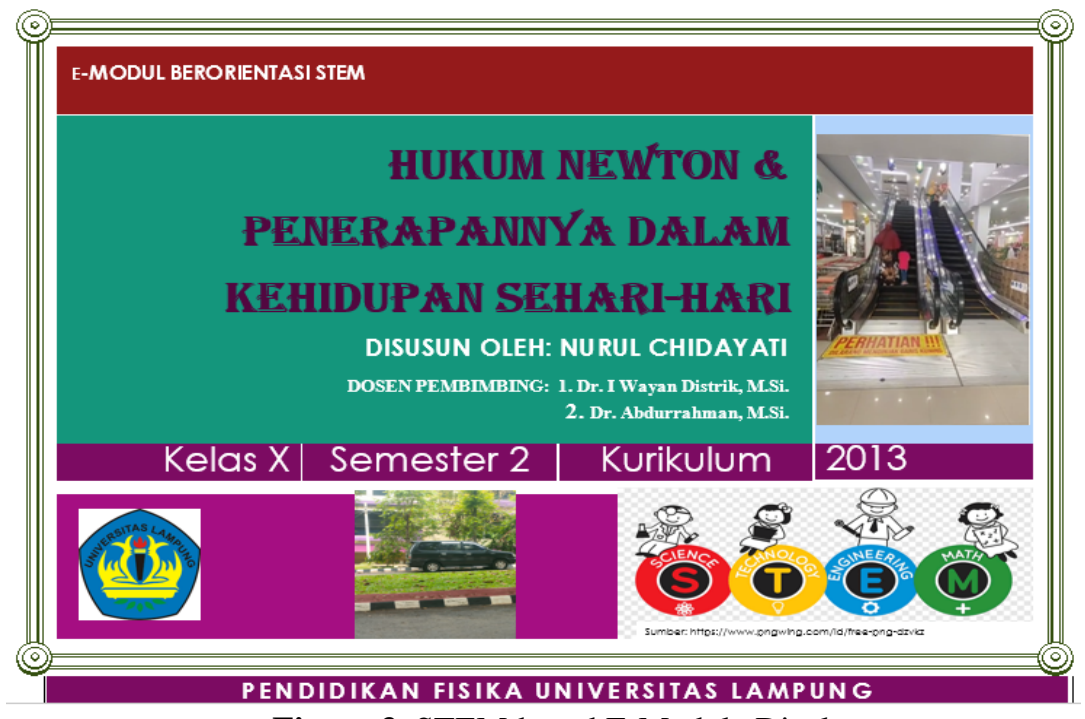

Figure 3. STEM-based E-Module Display

The results of the one-on-one test (small group trial) show that e-module products are interesting to learn because they provide convenience, both in grammar, material, and clarity of instructions. This product is the first module they have.

\subsection{Implementation}

At this stage, the product is implemented in learning. The subjects involved in this field test were grade 10 students of SMK Karya Wiyata Punggurk. At this stage, the emodule product is ready to be implemented for them to access either independently. Learning is carried out online through WhatsApp Groups that have been created by researchers.

Then, the researcher distributed a questionnaire on the practicality of using the product to all students. 


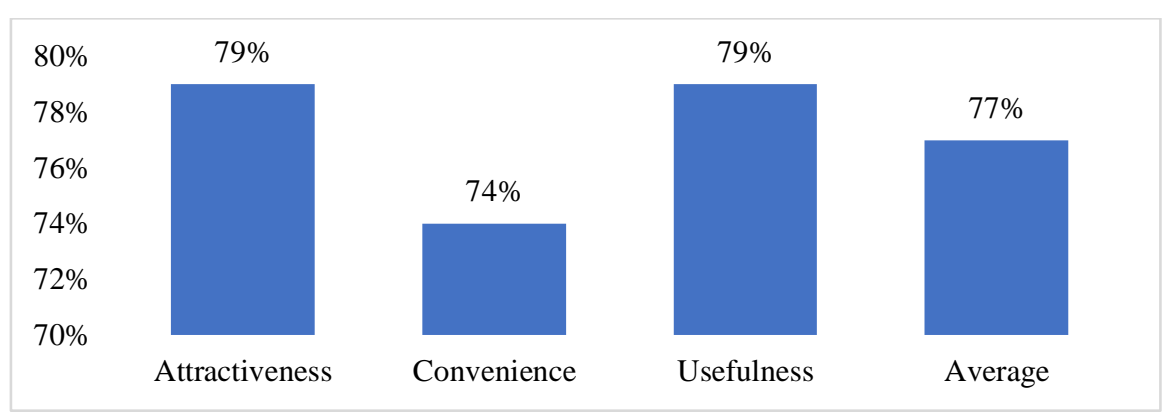

Figure 4. Results of Student Responses

Based on the implementation results, $79 \%$ of students stated that the e-module product was very interesting to use and $74 \%$ of students stated that this product was easy to use. $79 \%$ of students also stated that this product was very useful.

\subsection{Evaluation}

At the evaluation stage, the effectiveness of the product is tested. The effectiveness test contains 25 multiple choice HOTS questions to measure students' high-level thinking skills. Questions are distributed through a google form that is shared in a WhatsApp group which is used as a virtual class.

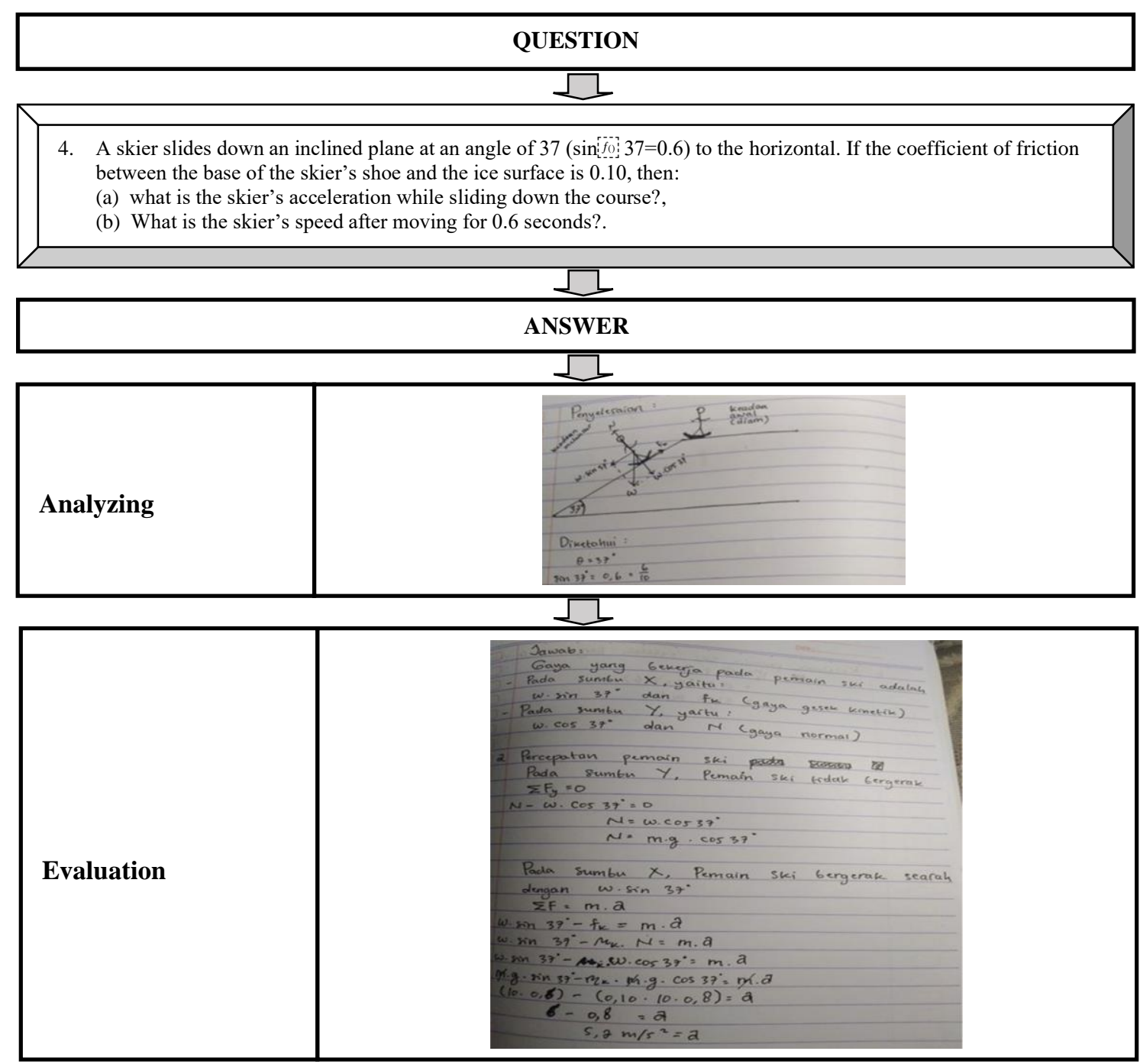

Figur 5. Examples of HOTS Questions and Student Answer 
The results of the effectiveness test can be seen in Table 3.

Table 3. Normality Test Results and Effectiveness Test

\begin{tabular}{lcccccc}
\hline & \multicolumn{3}{c}{ Kolmogorov-Smirnov } & \multicolumn{3}{c}{ Shapiro-Wilk } \\
\cline { 2 - 7 } & Statistic & df & Sig. & Statistic & df & Sig. \\
\hline Before Treatment &, 145 & 31 &, 097 &, 934 & 31 &, 057 \\
After Treatment &, 197 & 31 &, 004 &, 948 & 31 &, 138 \\
& a. Lilliefors Significance Correction & & & \\
\hline
\end{tabular}

Based on Table 3, the results of the normality test were obtained which stated that the Asymp value. Sig (2-tailed) of 0.057 and 0.138 . The result of the statistical hypothesis states that the value of sig $>0.05$ means that the data is normally distributed. In the next stage, testing was again carried out to see the differences in students' creative thinking abilities, before and after product implementation through the Paired Sample Test. The results of the Paired Sample Test are shown in Table 4.

Table 4. Correlations Paired Sample Test

\begin{tabular}{ccccc}
\hline & & $\mathbf{N}$ & Correlation & Sig. \\
\hline Pair 1 & Before Treatment and After Treatment & 31 &, 479 &, 006 \\
\hline
\end{tabular}

Based on table 6, it is known that the results of the correlations paired samples test and the Asymp value. Sig (2-tailed) of 0.006. The results of the statistical hypothesis stated that the value of sig $<0.05$, which means that there is a difference in the students' average HOTS. In addition to the correlations paired samples test, a paired samples test was also conducted, the results of which are shown in Table 5.

Table 5. Paired Sample Test

\begin{tabular}{|c|c|c|c|c|c|c|c|c|c|}
\hline & & \multicolumn{5}{|c|}{ Paired Differences } & \multirow{3}{*}{$\mathbf{t}$} & \multirow{3}{*}{ Df } & \multirow{3}{*}{$\begin{array}{c}\text { Sig. } \\
\text { (2-tailed) }\end{array}$} \\
\hline & & \multirow[t]{2}{*}{ Mean } & \multirow[t]{2}{*}{$\begin{array}{c}\text { Std. } \\
\text { Deviation }\end{array}$} & \multirow[t]{2}{*}{$\begin{array}{l}\text { Std. } \\
\text { Error } \\
\text { Mean }\end{array}$} & \multicolumn{2}{|c|}{$\begin{array}{l}\text { 95\% Confidence } \\
\text { Interval of the } \\
\text { Difference }\end{array}$} & & & \\
\hline & & & & & Lower & Upper & & & \\
\hline Pair 1 & $\begin{array}{c}\text { Before and } \\
\text { After } \\
\text { Treatment }\end{array}$ & $-16,323$ & 6,774 & 1,217 & $-18,807$ & $-13,838$ & $-13,415$ & 30 & ,000 \\
\hline
\end{tabular}

The result of the paired samples test is 0.000 . The results of the statistical hypothesis state that the value of sig $<0.05$, then there is a positive effect of STEM-based e-module on the results of students' higher-order thinking skills. This is in line with the results of the research of Mulyatiningsih which stated that the product is declared effective if the learning outcomes after treatment are better than the learning outcomes before treatment [31].

E-modules provide aspects of independence in learning for students. The attractive emodule design encourages students' curiosity, encourages students to interact with learning resources independently, and does not depend on others. This is in line with the research of Syahiddah et al. which states that the development of STEM-based physics e-modules is effective for controlling student learning outcomes independently [32]. Learning using e-modules gives a sense of interest and then in learning [33][34].

\section{CONCLUSION}

Based on the results of the research analysis, the STEM-based e-module product on Newton's law material is declared valid in content/material with a value of $82.2 \%$ (very good) and constructively valid with a value of $83.9 \%$ (very good), so that the e-module 
This module is suitable for use as teaching materials. Based on the product practicality test, judging from the student responses after using the product, students stated that this emodule was interesting with a score of $76.3 \%$, easy to use with a value of $75.7 \%$, and very useful with a value of $75.3 \%$, so the product was declared practical. to be used as teaching materials.

And based on the product effectiveness test, the $\mathrm{N}$-Gain value was 0.45 , which means that there was an increase in students' HOTS in the medium category. Overall, the development of STEM-based e-module products on Newton's Law material is feasible and effective to be used as learning material.

\section{REFERENCES}

[1] I. Sabri, "Peran Pendidikan Seni Di Era Society 5 . 0 untuk Revolusi," Pros. Semin. Nas. Pascasarjana UNNES, pp. 343-347, 2019, ISSN: 2686-6404

[2] Y. Puspita, Y. Fitriani, S. Astuti dan S. Novianti, "Selamat Tinggal Revolusi Industri 4.0, Selamat Datang Revolusi Industri 5.0," Pros. Sem. Nas. Pendidik. Program Pascasarjana Univ. PGRI Palembang, pp. 122-130, 2020

[3] F. E. Nastiti dan A. R. N. 'Abdu, "Kesiapan Pendidikan Indonesia Menghadapi Era Society 5.0," J. Kajian Teknologi Pendidik, vol. 5, no. 1, pp. 61-66, 2020, P-ISSN 2548-9879

[4] N. Izzati, dan I. Fatikhah, "Pengembangan Modul Pembelajaran Matematika Bermuatan Emotion Quotient Pada Pokok Bahasan Himpunan," Eduma: Mathematics Education Learning and Teaching, vol. 4, no. 2, pp. 46-61, 2015, doi.org/10.24235/eduma.v4i2.29

[5] M. Syahirah, L. Anwar, dan B.Holiwarni, "Pengembangan Modul Berbasis Stem (Science, Technology, Engineering And Mathematics) Pada Pokok Bahasan Elektrokimia,"J. Pijar MIPA, vol. 15, no. 4,pp. 317-324, 2020, doi.org/10.29303/jpm.v15i4.1602

[6] N. Izzati, dan I. Fatikhah, "Pengembangan Modul Pembelajaran Matematika Bermuatan Emotion Quotient Pada Pokok Bahasan Himpunan,"Eduma: Mathematics Education Learning and Teaching, vol. 4, no. 2, pp. 46-61, 2015, doi.org/10.24235/eduma.v4i2.29

[7] A. Permanasari, "STEM Education: Inovasi dalam Pembelajaran Sains," Semin. Nas. Pendidik. Sains, pp. 23-34, 2016

[8] D. M. P.Chania, R. Medriati, dan A. Mayub,"Pengembangan Bahan Ajar Fisika Melalui Pendekatan STEM Berorientasi HOTS pada Materi Usaha dan Energi,"J. Kumparan Fis., vol. 3, no. 2, pp. 109-120, 2020, doi.org/10.33369/jkf.3.2.109-120

[9] A. K. Sari, dan W. Trisnawati, "Integrasi Keterampilan Abad 21 dalam Modul Sociolinguistics: Keterampilan 4C ( Collaboration , Communication , Critical Thinking, Dan Creativity ), 'J. Muara Pendidik., vol. 4, no. 2, pp. 455-466, 2019, PISSN 2528-6250

[10] M. Syahirah, L. Anwar, dan B. Holiwarni, "Pengembangan Modul Berbasis Stem (Science, Technology, Engineering And Mathematics) Pada Pokok Bahasan Elektrokimia,"J. Pijar MIPA, vol. 15, no. 4, pp. 317-324, 2020, doi.org/10.29303/jpm.v15i4.1602.

[11] I. W. Redhana, "Mengembangkan Keterampilan Abad Ke-21 Dalam Pembelajaran Kimia,"J. Inov. Pendidik. Kimia, vol. 13, no. 1, pp. 2239-2253, 2020.

[12] Abdurrahman, "Developing STEM Learning Makerspace for Fostering Student's 21st Century Skills in the Fourth Industrial Revolution Era," J. of Physics: Conference Series, pp. 1-7, 2019, doi.org/10.1088/1742-6596/1155/1/012002. 
[13] D. U. Setyoningrum, R. S. Astuti, Si, M., dan U. Diponegoro, "Melalui Upaya Pemanfaatan Bonus Demografi (Dalam Rangka Menghadapi Tantangan Penyelenggaraan Pemerintahan Era 4.0),"Pros. Simposium. Nas., pp. 1291-1319, 2020, ISBN: 978-602-73470-5-2.

[14] A. Praswoto, Panduan Kreatif Membuat Bahan Ajar Inovatif. Yogyakarta: Diva Press, 2011.

[15] T. Mulyani, "Pendekatan Pembelajaran STEM untuk menghadapi Revolusi," Semin. Nas. Pasc., pp. 453-460, 2019.

[6] H. N. Dinni, "HOTS ( High Order Thinking Skills ) dan Kaitannya dengan Kemampuan Literasi Matematika,"Pros. Semin. Nas. Mat., pp. 170-176, 2018.

[17] I. W. Widana, "Modul Penyusunan Higher Order Thingking Skill (HOTS),"Direktorat Pembinaan SMA Direktorat Jenderal Pendidikan Dasar Dan Menengah Departemen Pendidikan Dan Kebudayaan, pp. 1-46, 2017.

[18] Kemendikbud., "Surat Edaran Menteri Pendidikan Dan Kebudayaan Nomor 4 Tahun 2020 Tentang Pelaksanaan Kebijakan Pendidikan Dalam Masa Darurat Penyebaran Coronavirus Disease (COVID-19),"Hukum Online, pp. 1-3, 2020.

[19] R. Azizah, L. Yuliati, dan E. Latifah, "Kesulitan Pemecahan Masalah Fisika pada Siswa SMA,"J. Penelitian Fis. dan Aplikasinya (JPFA), vol. 5, no. 2, pp. 44-50, 2015, doi.org/10.26740/jpfa.v5n2.p44-50.

[20] I. Rinsiyah, "Pengembangan Modul Fisika Berbasis CTL untuk Meningkatkan KPS dan Sikap Ilmiah Siswa Madrasah Aliyah,"J. Pendidik. Mat. dan Sains, vol. 4, no. 2, pp. 152-162, 2016, ISSN 1410-1866.

[21] D. Januarifin, danA. Hidayat, "Kesalahan siswa SMA dalam memecahkan masalah pada materi Hukum," vol. 2, no. 2, pp. 47-55, 2018.

[22] N. C. Nisa, N. Nadiroh, dan E. Siswono, "Kemampuan Berpikir Tingkat Tinggi (HOTS) tentang Lingkungan Berdasarkan Latar Belakang Akademik Siswa,"J. Ilmiah Pendidik. Lingkungan dan Pembangunan, vol. 19, no. 2, pp. 1-14, 2018, doi.org/10.21009/plpb.192.01

[23] P. M. S. Saraswati, dan N. G. S. Agustika, "Kemampuan Berpikir Tingkat Tinggi Dalam Menyelesaikan Soal HOTS Mata Pelajaran Matematika, J. Ilmiah Sekolah Dasar, vol.4, no. 2, pp. 257-269, 2020, ISSN: 2579-3276

[24] H. N.Dinni, "HOTS ( High Order Thinking Skills ) dan Kaitannya dengan Kemampuan Literasi Matematika," Pros. Semin. Nas. Mat., pp. 170-176, 2018.

[25] J. Handhika, Cari, A. Soeparmi,dan W. Sunarno, "Student Conception and Perception of Newton's Law," AIP Conference Proceedings, pp. 1-5, 2016, doi.org/10.1063/1.4941178.

[26] N. D. Setyani, dan J. Handhika, "Analisis Kesalahan Mahasiswa dalam Menyelesaikan Soal Multirepresentasi pada Materi Kinematika dan Dinamika,"Prosiding SNPF (Semin. Nas. Pendidik. Fis.), pp. 121-127, 2016.

[27] N. D. Setyani, J. Handhika, dan Cari, "Analisis Kesalahan Mahasiswa dalam Menyelesaikan Soal Multirepresentasi pada Materi Kinematika dan Dinamika. Pros. SNPF (Semin. Nas. Pendidik. Fis.), pp. 121-127, 2016.

[28] R. M. Branch, Instructional Design: The ADDIE Approach. London: Springer, 2009

[29] D. Rusman, Kurniaan dan C. Riyana, Pembelajaran Berbasis Teknologi Informasi Dan Konumikasi. Jakarta: Raja Grafindo Persada, 2012.

[30] H. Pratama, dan A. C. Yusro, "Implementasi WhatsApp Mobile Learning Untuk Meningkatkan Hasil Belajar Mahasiswa Pokok Bahasan Pengenalan Komponen Elektronika,"J. Pendidik. Fis. dan Keilmuan (JPFK), vol. 2, no. 2, pp. 65-69, 2016, doi.org/10.25273/jpfk.v2i2.696 
[31] E. Mulyatiningsih, Riset Terapan Bidang Pendidikan dan Teknik, Yogyakarta: UNY Press, 2011.

[32] D. S. Syahiddah, P. Dwi. A.P, dan B. Supriadi, "Pengembangan E-Modul Fisika Berbasis STEM (Science, Technology, Engineering, and Mathematics) Pada Materi Bunyi di SMA/MA," J. Literasi Pendidik. Fis., vol. 2, no. 1, 1-8. P-ISSN: 2714-5689.

[33] D. Wahyudi, "Pengembangan E-Modul Dalam Pembelajaran (Development Of EModules In Learning Math High)," J. Pendidik. Mat., vol. 02, no. 02, pp. 1-10, 2019, doi.org/doi.org/10.30656/gauss.v2i2.1739

[34] R. Arnila, S. Purwaningsih, dan Nehru, "Pengembangan E-Modul Berbasis STEM (Science, Technology, Engineering And Mathematic) Pada Materi Fluida Statis Dan Fluidadinamis Menggunakan Kivosft Flipbook Maker," J. Edumaspul, vol. 5, no. 1, pp. 551-556, 2021, P-ISSN: 2548-8201 